\title{
PERINGKAT FAKTOR PENYEBAB YANG MEMPENGARUHI TERJADINYA KLAIM DARI KONTRAKTOR KE OWNER PADA PROYEK KONSTRUKSI DI KOTA PADANG
}

\author{
VIVI ARIANI ${ }^{1}$, FIELDA ROZA ${ }^{2}$, EMBUN SARI AYU ${ }^{3}$ \\ Fakultas Teknik Sipil dan Perencanaan, Universitas Bung Hatta ${ }^{1,2,3}$ \\ viviariani@bunghatta.ac.id ${ }^{1}$
}

\begin{abstract}
This article presents the results of a survey on the potential for claiming by service providers based on their experience and understanding of the demands that are the responsibility of the project owner (service users) in private and government projects in Padang City. This study aims to identify the factors that cause demands / claims on construction projects. The writing of this article is organized as follows: First, a literature review related to construction claims is presented and followed by a potential survey of claims made by service providers. Next is analysis and discussion and ends with conclusions and recommendations. This research methodology was designed in the form of quantitative research by distributing questionnaire surveys to construction industry practitioners to answer research objectives. Collecting questionnaire survey data was carried out to stakeholders of construction projects in the City of Padang, including project owners (owners), planning consultants, supervisory consultants and contractors. Data analysis techniques were carried out using descriptive statistics, namely: mean and standard deviation. Mean is used to determine the average value of the number of responses for each available answer. Furthermore, based on the mean and standard deviations, the ranking of each statement is determined. The analysis is continued by calculating the natural cut-off point to reduce rank/ rank. From the results of the analysis, obtained 12 factors (of 28 factors) the cause of the construction claim by the contractor against the project owner. The output of the research is expected to help project managers to facilitate the submission process and the efficiency of successful construction project claims.
\end{abstract}

Keywords: Claims, Construction Project, Contractor, Owner

Abstrak: Penelitian ini mempresentasikan hasil survei tentang penentuan peringkat faktor yang mempengaruhi terjadinya pengajuan klaim oleh penyedia jasa berdasarkan pengalaman dan pemahaman yang dimiliki atas tuntutan yang menjadi tanggung jawab pemilik proyek (pengguna jasa) pada proyek-proyek swasta dan pemerintah di Kota Padang. Penelitian ini bertujuan untuk mengidentifikasi faktor penyebab terjadinya tuntutan/klaim pada proyek konstruksi. Adapun pelaksanaan penulisan artikel ini diorganisasikan sebagai berikut: Pertama kajian literatur terkait klaim konstruksi dipaparkan dan diikuti dengan penyebab terjadinya pengajuan klaim yang dilaksanakan oleh penyedia jasa. Selanjutnya adalah analisis dan diskusi dan diakhiri oleh konklusi dan rekomendasi. Metodologi penelitian ini didesain bentuk penelitian kuantitatif dengan penyebaran survey kuesioner kepada praktisi industri konstruksi untuk menjawab tujuan penelitian. Pengumpulan data survey kuesioner dilakukan kepada stakeholder proyek konstruksi di Kota Padang, meliputi pemilik proyek (owner), konsultan perencana, konsultan pengawas dan kontraktor. Teknik analisa data dilakukan dengan menggunakan statistik deskriptif yaitu: rata-rata (mean) dan standar deviasi. Mean digunakan untuk mengetahui nilai rata-rata dari jumlah respon untuk tiap jawaban yang tersedia. Selanjutnya berdasarkan mean dan standar deviasi ditetapkan rangking masing-masing pernyataan. Analisa dilanjutkan dengan menghitung natural cut off point untuk mereduksi peringkat/rangking. Dari hasil analisa, diperoleh 12 faktor (dari 28 faktor) penyebab terjadinya klaim konstruksi oleh kontraktor terhadap pemilik proyek. Luaran penelitian diharapkan dapat membantu manajer proyek untuk mempermudah proses pengajuan dan efisiensi keberhasilan klaim proyek konstruksi.

Kata kunci: Klaim, Proyek Konstruksi, Kontraktor dan Pemilik PENDAHULUAN

Klaim dalam industri konstruksi kepada permohonan terhadap pertambahan biaya dan pertambahan waktu serta memicu merupakan masalah yang dapat mengacu terjadinya perselisihan antara pemilik 
bangunan dengan kontraktor. Permohonan pertambahan waktu pelaksanaan proyek konstruksi tidak hanya berimbas terhadap kinerja pelaksanaan proyek tetapi juga berimbas terhadap pemakaian anggaran biaya pelaksanaan proyek konstruksi. Dengan demikian, kontraktor berhak mengajukan klaim konstruksi.

Di Indonesia fenomena tentang klaim, terutama dalam pengertian yang sempit yaitu klaim dari pelaksana (kontraktor), masih dianggap tabu oleh kebanyakan pihak yang telibat dalam proyek konstruksi karena berbagai alasan. Bagi pemilik bangunan, khususnya pemerintah merasa alergi dengan istilah klaim sementara kontraktor merasa segan untuk mengajukan klaim karena takut dicatat sebagai kontraktor yang rewel atau menuntut macam-macam (Yasin, 2004).

Penelitian ini diorganisasikan sebagai berikut: pertama kajian literatur terdahulu terkait klaim konstruksi dipaparkan dan diikuti dengan hasil peringkat faktor terjadinya pengajuan klaim yang dilaksanakan oleh kontraktor. Selanjutnya adalah analisa dan diskusi dan diakhiri oleh kesimpulan dan rekomendasi. Adapun rumusan masalah yang akan dibahas adalah faktor apa saja yang menyebabkan terjadinya klaim konstruksi oleh kontraktor ke owner pada proyek konstruksi dan urutan peringkatnya. Untuk menjawab rumusan masalah tersebut maka disusunlah tujuan penelitian ini yaitu untuk mengidentifikasi faktor penyebab terjadinya klaim dan untuk megurutkan peringkat utama faktor penyebab terjadinya klaim konstruksi.

Studi terdahulu oleh Wibowo (2009) membahas tentang persepsi pengajuan klaim atas keterlambatan akibat pihak pemilik pada proyek konstruksi pemerintah. Hasil survei persepsi tentang praktik klaim dari kontraktor kepada pemilik akibat keterlambatan yang disebabkan pemilik tentang alasan-alasan klaim tidak diajukan oleh kontraktor dan alasan ditolak oleh pemilik. Tiga alasan utama meliputi, klaim tidak cukup signifikan, ketidaksiapan dokumen klaim dan prosedur administratif yang berbelit. Seeley (1993) mengkategorikan klaim menjadi tiga sebagai conctractual claims, ex-contractual claims dan common law claims. Sementara itu, Stokes (1990) merumuskan empat strategi bagi kontraktor supaya klaim berhasil yaitu, mengenali klaim, memberikan notifikasi dengan tepat, mengumpulkan dokumentasi yang diperlukan dan mempresentasikan klaim dengan cara persuasif supaya pemilik mengabulkan klaim. Arditi dan Pattanakichamroon (2008) melakukan studi atas 58 kasus klaim terkait dengan perselisihan tentang waktu pada proyek-proyek pemerintah. Berdasarkan studi yang dilakukan, faktor penyebab klaim adalah kondisi lapangan yang berbeda dengan desain/spesifikasi dan change order untuk pekerjaan tambah dan ketidakpastian cuaca.

Chandra, et al. (2005) mengemukakan 9 faktor penyebab terjadinya klaim konstruksi yaitu, compensable delay, Perubahan jadwal, Perubahan atau modifikasi isi kontrak, Perbedaan kondisi lapangan, Perubahan kondisi cuaca di luar musim, Kegagalan dalam membuat kesepakatan harga, Konflik dalam perancangan dan spesifikasi, Produk yang sudah tidak diproduksi lagi dan Kontrak yang tersendat-sendat.

Sedangkan Prof. H. Priyatna Abdurrasyid dalam Tela (2007) mengemukakan 11 faktor penyebab terjadinya klaim yaitu; Informasi design yang tidak tepat, Informasi design yang tidak sempurna, Investigasi lokasi yang tidak sempurna, Reaksi klien yang lambat, Komunikasi yang buruk, Sasaran waktu yang tidak realistis, Administrasi kontrak yang tidak sempurna, Kejadian eksternal yang tidak terkendali, informasi tender yang tidak lengkap, Alokasi risiko yang tidak jelas dan Keterlambatan/ingkar membayar. Robert D. Gilbreath dalam Yasin (2004) mengemukakan terdapat 4 faktor yaitu; Pekerjaan yang cacat, Kelambatan yang disebabkan penyedia jasa dan Sebagai klaim tandingan. Lebih lanjut Soekirno (2005) terdapat 3 faktor penyebab terjadinya klaimAdanya faktor ketidakpastian dalam setiap proyek konstruksi, Masalah yang berhubungan dengan kontrak konstruksi dan Perilaku oportunis dari pihak yang terlibat dalam suatu proyek konstruksi.

Faktor dokumen kontrak merupakan faktor utama penyebab klaim konstruksi menurut Ahuja dalam Handayani (2010). Hal ini sejalan dengan pendapat Nurisra (2010) yaitu terdapatnya Pasal-pasal kontrak yang kurang lengkap dan jelas. Sedangkan Menurut Dipohusodo dalam Putri (2012) situasi yang berpotensi membangkitkan klaim adalah:

$\begin{array}{lr}\text { Fakultas Teknik UMSB } & \text { ISSN 2599-2081 } \\ \text { EISSN 2599-2090 }\end{array}$


1. Keterlambatan dalam penyerahan gambargambar dan klarifikasi.

2. Terdapat cacat dalam spesifikasi yang diterima, cacat dalam persetujuan kontrak/penyimpangan volume pekerjaan yang ketentuannya tidak terdapat didalam kontrak.

3. Keterlambatan dalam penyerahan material, cacat pabrik pada material/peralatan yang merupakan bagian dari barang-barang yang disediakan dan menjadi kewajiban pihak pemberi tugas.

4. Perubahan hukum, tata cara/peraturan yang berhubungan dengan penunjukan pemenang lelang.

5. Perubahan atau penyimpangan kondisi lapangan, berbeda dengan yang diinformasikan semula.

6. Penundaan/pemberhentian pekerjaan karena proses pelaksanaan pekerjaan kontraktor lain/penahanan laju pekerjaan oleh pemberi tugas demi untuk kepentingannya.

7. Upaya mempercepat penyelesaian pekerjaan di luar jadwal dalam rangka memenuhi kebutuhan pemberi tugas di luar kesepakatan.

8. Keterlambatan yang cukup berarti dalam membayar pekerjaan, memberikan ijin, persetujuan, keputusan perintah perubahan dan tanggapan atas klaim.

9. Penundaan yang terlalu lama dalam penyerahan laporan/keputusan akhir kontrak yang mengambang dari pemberi tugas.

10. Kegagalan pemberi tugas dalam menjalankan tugas dan fungsinya

11. Penolakan yang tak beralasan atas hasil pekerjaan yang sudah sesuai spesifikasi atau yang seharusnya sudah dapat diterima.

12. Penjadwalan ulang/perpanjangan waktu pelaksanaan pekerjaan karena alasan penyediaan keuangan/sebab lain yang semacam.

13. Pekerjaan tambah yang muncul selama masa pemeliharaan, yang tidak tercakup sebagai tugas kontraktor.

14. Kegagalan kinerja subkontraktor yang ditunjuk oleh pemberi tugas.

15. Ketentuan spesifikasi yang tidak tegas seperti penggunaan kalimat atau yang setara dengan merk tertentu dan sebagaimana mungkin diperlukan yang terkait dengan material.

16. Ketentuan yang cenderung mengarah pada ketidak mungkinan untuk memenuhi/tidak sesuai dengan pekerjaan kontrak.

17. Tindakan yang diijinkan dan sesuai dengan kontrak tetapi tanpa disertai ketentuan kompensasi yang setara.

18. Force majeure.

Lebih lanjut Putri (2012) membagi faktor penyebab klaim menjadi faktor pemilik, faktor konsultan perencana, faktor konsultan pengawas dan faktor eksternal. Dimana faktor penyebab klaim kontruksi dari pihak pemilik proyek terdiri dari:

1. Keterlambatan dalam penyerahan gambar- gambar.

2. Keterlambatan dalam menyediakan material.

3. Penundaan pekerjaan karena alasan tertentu.

4. Percepatan penyelesaian pekerjaan diluar jadwal.

5. Keterlambatan dalam memberikan ijin.

6. Pembayaran termin tidak tepat waktu.

7. Perubahan desain.

Dilanjutkan dengan faktor penyebab klaim konstruksi dari pihak konsultan perencana terdiri dari:

1. Gambar bestek tidak jelas/kurang lengkap.

2. Gambar tidak mungkin dilaksanakan.

3. Perubahan mutu material/bahan.

4. Standar material yang ditentukan dalam spesifikasi teknis tidak ada di pasaran.

5. Kondisi lapangan berbeda dengan kondisi yang dicantumkan dalam kontrak.

6. Kondisi bawah tanah berbeda dengan kondisi yang dicantumkan dalam kontrak.

Sedangkan faktor penyebab klaim konstruksi dari pihak konsultan pengawas terdiri dari:

1. Terlambat menyetujui proses pelaksanaan pekerjaan.

2. Terlambat melakukan pemeriksaan material/bahan.

3. Tidak mengevaluasi kemajuan prestasi pekerjaan kontraktor.

4. Penundaan pekerjaan karena alasan tertentu.

Untuk faktor penyebab klaim konstruksi dari faktor eksternal terdiri dari: 
1. Curah hujan yang lebih tinggi dari biasanya/hujan lebat berhari-hari.

2. Kebijakan pemerintah pusat/daerah yang diterbitkan setelah penandatanganan kontrak yang mempengaruhi sasaran proyek (biaya, mutu dan waktu).

3. Kenaikan harga material dan upah tenaga kerja.

4. Force majeur.

5. Kondisi sosial budaya masyarakat di sekitar proyek.

\section{METODE PENELITIAN}

Metode penelitian yang digunakan adalah penelitian kuantitatif melalui survey kuesioner kepada penyedia dan pengguna barang dan jasa di Kota Padang.

Analisa data menggunakan analisa statistik deskriptif dan inferensial. Pada analisa statistik deskriptif digunakan untuk menggambarkan tentang ringkasan data-data penelitian seperti mean, standar deviasi dan lain-lain. Analisa data yang digunakan adalah:

1. Statistik deskriptif

Data penelitian dianalisa dengan menggunakan teknik deskriptif dan inferensial. Dimana teknik deskriptif ini dilakukan untuk menggambarkan data, sedangkan teknik analisa inferensial digunakan untuk menyimpulkan hasil uji hipotesa (Trochim, 2006).

- Distribusi Frekuensi (frequency distribution)

Agar dapat mendeskripsikan data dapat tergambarkan dengan distribusi frekunsi yang jelas seperti: jumlah dari frekuensi, persentase dan kumulatif persentase, maka dicari pencapaian dengan rumus (Arikunto, 2006).

Distribusi frekuensi $=\frac{n}{\Sigma N} x 100 \%$

Dimana :

$\sum \mathrm{N}$ : jumlah total dari responden

$\mathrm{n} \quad$ : jumlah total respon tiap jawaban yang tersedia

- Rata-rata (mean)

Rata-rata digunakan untuk mengetahui nilai rata-rata dari jumlah respon untuk tiap jawaban yang tersedia. Selanjutnya berdasarkan mean dan standar deviasi ditetapkan rangking masing-masing pernyataan. Analisa dilanjutkan dengan menghitung natural cut off point yang merupakan nilai rata-rata dari mean terbesar dan terkecil dengan rumus:

Natural cut off point $=($ mean maksimal + mean minimal) / 2 ......... (Lewa, 2017)

Maksud dari dihitungnya natural cut off point ini adalah untuk mereduksi jumlah variabel pada masing-masing kelompok sehingga diperoleh kelompok variabel yang dapat dikategorikan sering terjadi atau dominan digunakan sehingga perlu mendapat perhatian.

Untuk pengolahan dan analisa data, penelitian ini menggunakan Microsoft Excel 2010 dan SPSS Statistic 20.0 for windows.

2. Statistik Inferensial

Statistik inferensial adalah sebuah prosedur yang diterapkan untuk menetapkan karakteristik populasi melalui sampel. Analisa statistik inferensial yang digunakan adalah Cronbach's Alpha. Uji reliabilitas digunakan untuk mengetahui konsistensi alat ukur, apakah alat pengukur yang digunakan dapat diandalkan dan tetap konsisten jika pengukuran tersebut diulang. Pada penelitian ini, konsistensi masing-masing individu dalam merespon item-item pertanyaaan dapat diukur dengan Cronbach's Alpha. Menurut Santos dalam Sesmiwati (2017) Cronbach's Alpha adalah sebuah perangkat yang efektif untuk menganalisa realibilitas variabel yang dihasilkan dari kuesioner yang dikembalikan oleh para responden. Uji signifikansi dilakukan pada taraf signifikansi 0.05 artinya instrumen dapat dikatakan reliabel bila nilai alpha lebih besar dari $r$ kritis product moment.

Menurut Field dalam Sesmiwati (2017), masing-masing item harus memiliki hubungan dengan skor total dari kuesioner. Nilai dalam kolom corrected item-total correlation menunjukkan hubungan ini. Nilai ini harus diatas 0.3 untuk menunjukkan bahwa hubungan yang terjadi antara masing-masing item dengan skor total kuesioner. Jika ditemukan skor kurang dari 0.3 maka item tersebut harus dihilangkan.

$\begin{array}{lrr}\text { Fakultas Teknik UMSB } & \text { ISSN 2599-2081 } \\ \text { EISSN 2599-2090 }\end{array}$


HASIL DAN PEMBAHASAN

1. Statistik Deskriptif

Data umum responden

a. Tempat bekerja

\section{Tempat Bekerja}
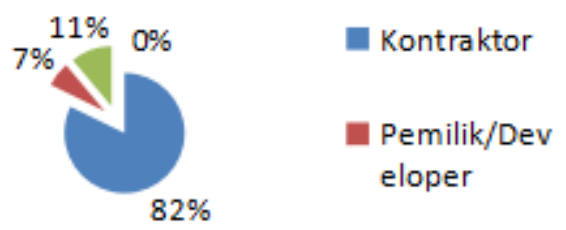

Gambar 1. Persentase Tempat Bekerja Responden

Dari gambar 1. di atas dapat diketahui bahwa responden penelitian ini didominasi oleh kontraktor sebesar $82,22 \%$ sedangkan konsultan sebesar $11,11 \%$ dan pemilik/developer sebesar $6.67 \%$. data peran perusahaan dimana responden bekerja diperlukan sebagai pertimbangan dalam menganalisa data survey kuesioner.

b. Pendidikan terakhir

\begin{tabular}{|c|}
\hline $\begin{array}{l}\text { Pendidikan } \\
\text { = Diploma tiga (D3) } \\
\text { = Sarjana (S1) } \\
\text { " Pascasarjana (S2/S3) } \\
8 \% \%\end{array}$ \\
\hline
\end{tabular}

Gambar 2. Latar Belakang Pendidikan Responden

Berdasarkan gambar 2. di atas tingkat pendidikan para responden yang terlihat dengan pendidikan akhir sarjana (S1) yaitu sebesar $80 \%$, pascasarjana (S2) $6.67 \%$ dan diploma tiga (D3) sebesar $13.33 \%$.

c. Level/posisi jabatan dalam perusahaan atau institusi

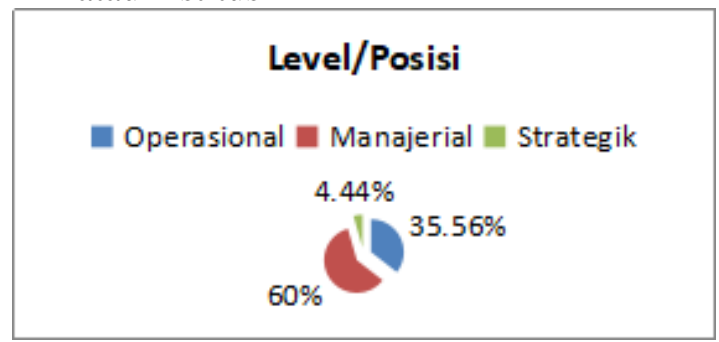

Gambar 3. Persentase Posisi/Jabatan
Dari gambar 3. diatas jabatan para responden terbagi atas manajerial sebesar $60 \%$, jabatan operasional sebesar $35,56 \%$ dan jabatan strategik $4,44 \%$.

d. Spesialisasi bidang pekerjaan

\begin{tabular}{|c|c|}
\hline \multicolumn{2}{|c|}{ Spesialisasi bidang kerja } \\
\hline Konstruksi bagunan gedung & $47.54 \%$ \\
\hline [ Konstruksi bangunan sipil & $40.98 \%$ \\
\hline $\begin{array}{l}\text { Konstruksi bangunan elektrikal } \\
\text { dan komunikasi }\end{array}$ & $8.2 \%$ \\
\hline $\begin{array}{c}\text { Gambar 4. Persentase Spesialis } \\
\text { Kerja }\end{array}$ & \\
\hline
\end{tabular}
bahwa responden lebih banyak terlibat pada konstruksi bangunan gedung sebesar 47,54\% dan konstruksi bangunan sipil sebesar 40,98\%. sedangkan yang terlibat dalam konstruksi bangunan elektrikal/ komunikasi sebesar $8,20 \%$, dan lain-lain 3,48\%

e. Nilai konstruksi tertinggi

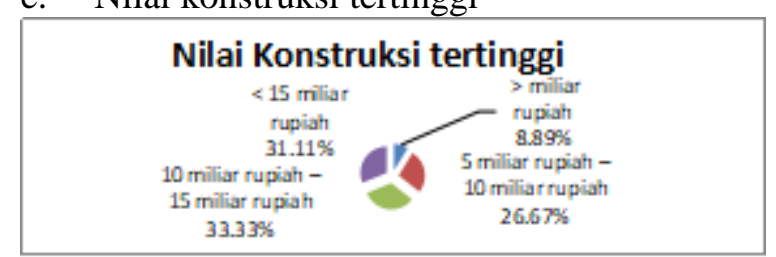

Gambar 5. Persentase Nilai konstruksi tertinggi

Dari gambar di atas, responden memiliki pengalaman berdasarkan nilai konstruksi tertinggi yaitu kurang dari 5 milyar rupiah sebesar 8,89\%, 5 miliar rupiah - 10 miliar rupiah sebesar 26,67\%, 10 miliar rupiah - 15 miliar rupiah sebesar 33,33\% dan lebih dari 15 miliar rupiah sebesar $31,11 \%$.

f. Pengalaman

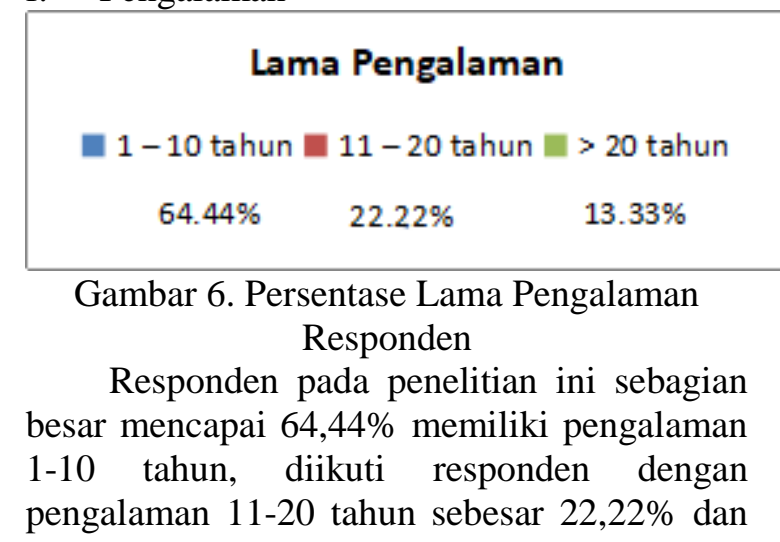


pengalaman lebih dari 20 tahun sebesar $13,33 \%$.

Analisa juga dilakukan dengan menghitung mean dan standar deviasi masingmasing variabel. Selanjutnya berdasarkan mean ditentukan rangking tiap variabel berdasarkan nilai mean tersebut. Hasil analisa secara menyeluruh dapat dilihat pada tabel 1 dibawah ini:

Tabel 1 Faktor Penyebab terjadinya Klaim Konstruksi

\begin{tabular}{|c|c|c|c|c|c|c|c|c|c|}
\hline \multicolumn{5}{|c|}{ Nomstunst } & \multirow{4}{*}{$x 8$} & \multirow{4}{*}{$\begin{array}{l}\text { Waktu yang } \\
\text { diberikan } \\
\text { owner untuk } \\
\text { inspeksi } \\
\text { lapangan } \\
\text { tersebut } \\
\text { terlalu } \\
\text { singkat }\end{array}$} & & \multirow{4}{*}{0.97} & \\
\hline Kode & $\begin{array}{l}\text { Faktor } \\
\text { Penyebab } \\
\text { Klaim }\end{array}$ & Mean & SD & $\begin{array}{l}\text { Ran } \\
\mathbf{k}\end{array}$ & & & & & \\
\hline 1 & $\begin{array}{l}\text { Keterlambat } \\
\text { an akibat } \\
\text { owner }\end{array}$ & & & & & & & & \\
\hline \multirow[t]{2}{*}{$\mathrm{X} 1$} & \multirow{2}{*}{$\begin{array}{l}\text { Owner } \\
\text { terlambat } \\
\text { menyetujui } \\
\text { shop drawing }\end{array}$} & \multirow[t]{2}{*}{2.76} & \multirow[t]{2}{*}{0.93} & \multirow[t]{2}{*}{22} & & & & & \\
\hline & & & & & 3 & $\begin{array}{l}\text { Kondisi } \\
\text { cuaca diluar } \\
\text { musim }\end{array}$ & & & \\
\hline $\mathrm{X} 2$ & $\begin{array}{l}\text { Owner } \\
\text { terlambat } \\
\text { menyetujui } \\
\text { sample yang } \\
\text { diajukan } \\
\text { kontraktor } \\
\end{array}$ & 2.60 & 0.84 & 26 & \multirow[t]{2}{*}{ X9 } & $\begin{array}{l}\text { Curah hujan } \\
\text { yang lebih } \\
\text { tinggi dari } \\
\text { biasanya } \\
\text { sehingga } \\
\text { menghambat }\end{array}$ & 3.82 & 0.81 & 1 \\
\hline \multirow[t]{2}{*}{$\mathrm{X} 3$} & \multirow{2}{*}{$\begin{array}{l}\text { Owner } \\
\text { terlambat } \\
\text { menyetujui } \\
\text { perubahan } \\
\text { desain }\end{array}$} & \multirow[t]{2}{*}{2.78} & \multirow[t]{2}{*}{0.82} & \multirow[t]{2}{*}{20} & & $\begin{array}{l}\text { pekerjaan } \\
\text { proyek }\end{array}$ & & & \\
\hline & & & & & $\mathrm{X} 10$ & $\begin{array}{l}\text { Badai, topan } \\
\text { dan angin } \\
\text { ribut yang }\end{array}$ & 2.60 & 0.99 & 25 \\
\hline \multirow[t]{3}{*}{$\mathrm{X} 4$} & \multirow{3}{*}{$\begin{array}{l}\text { Owner } \\
\text { terlambat } \\
\text { mengeluar } \\
\text { kan change } \\
\text { order, } \\
\text { sehingga } \\
\text { menyebabkan } \\
\text { pekerjaan } \\
\text { proyek } \\
\text { tertunda }\end{array}$} & \multirow[t]{3}{*}{2.76} & \multirow[t]{3}{*}{0.86} & \multirow[t]{3}{*}{23} & & $\begin{array}{l}\text { terjadi pada } \\
\text { saat } \\
\text { pelaksanaan } \\
\text { proyek }\end{array}$ & & & \\
\hline & & & & & X11 & $\begin{array}{l}\text { Hujan deras } \\
\text { yang terus } \\
\text { menerus atau } \\
\text { kondisi cuaca } \\
\text { buruk }\end{array}$ & 3.78 & 0.93 & 2 \\
\hline & & & & & $\mathrm{X} 12$ & Terjadi banjir & 2.69 & 1.12 & 24 \\
\hline 2 & $\begin{array}{l}\text { Perbedaan } \\
\text { kondisi } \\
\text { lapangan }\end{array}$ & & & & & $\begin{array}{l}\text { ditempat } \\
\text { pekerjaan } \\
\text { proyek }\end{array}$ & & & \\
\hline $\mathrm{X} 5$ & $\begin{array}{l}\text { Penyelidikan } \\
\text { tanah yang } \\
\text { dilakukan } \\
\text { owner tidak } \\
\text { sesuai }\end{array}$ & 3.02 & 1.25 & 11 & & $\begin{array}{l}\text { sehingga } \\
\text { penyedia jasa } \\
\text { tidak bisa } \\
\text { melanjutkan } \\
\text { pekerjaan }\end{array}$ & & & \\
\hline X6 & $\begin{array}{l}\text { Kondisi } \\
\text { lapangan } \\
\text { yang berbeda }\end{array}$ & 2.87 & 1.14 & 15 & 4 & $\begin{array}{l}\text { Percepatan } \\
\text { kerja atas } \\
\text { perintah }\end{array}$ & & & \\
\hline
\end{tabular}

dengan

kondisi awal

pada saat

kontrak

ditanda

tangani

\begin{tabular}{llrlll}
\hline X7 & $\begin{array}{l}\text { Hasil } \\
\text { tanah }\end{array}$ & $\begin{array}{r}\text { tes } \\
\text { yang }\end{array}$ & 2.82 & 1.05 & 18
\end{tabular}

diperoleh

kurang akura

\begin{tabular}{llllll}
\multicolumn{7}{c}{ kurang akurat } \\
\hline X8 & Waktu yang & 2.98 & 0.97 & 14
\end{tabular}

singkat

cuaca diluar

Curah hujan

sehingga

menghambat

pekerjaan

dan angin

ribut yang

terjadi pada

saat

pelaksanaan

yang terus

menerus atau

kondisi cuaca

ditempat

penyedia jasa

tidak bisa

melanjutkan

kerja atas

EISSN 2599-2090 


\begin{tabular}{|c|c|c|c|c|c|c|c|c|c|}
\hline & $\begin{array}{l}\text { pengguna } \\
\text { jasa }\end{array}$ & & & & & $\begin{array}{l}\text { pengguna } \\
\text { jasa }\end{array}$ & & & \\
\hline $\mathrm{X} 13$ & $\begin{array}{l}\text { Peningkatan } \\
\text { produktivitas } \\
\text { dengan waktu } \\
\text { lembur lebih } \\
\text { sering terjadi }\end{array}$ & 3.78 & 0.74 & 3 & 6 & $\begin{array}{l}\text { Kegagalan } \\
\text { kesepakatan } \\
\text { harga } \\
\text { perubahan } \\
\text { pekerjaan. }\end{array}$ & & & \\
\hline \multirow[t]{2}{*}{$\mathrm{X} 14$} & \multirow{2}{*}{$\begin{array}{l}\text { Pekerjaan } \\
\text { dengan waktu } \\
\text { lembur yang } \\
\text { lama } \\
\text { membuat } \\
\text { produktivitas } \\
\text { menurun }\end{array}$} & \multirow[t]{2}{*}{3.20} & \multirow[t]{2}{*}{0.89} & \multirow[t]{2}{*}{8} & $\mathrm{X} 21$ & $\begin{array}{l}\text { Perubahan } \\
\text { gambar oleh } \\
\text { owner }\end{array}$ & 3.02 & 1.06 & 12 \\
\hline & & & & & X22 & $\begin{array}{l}\text { Perubahan } \\
\text { metode } \\
\text { pelaksanaan } \\
\text { yang }\end{array}$ & 3.36 & 0.74 & 7 \\
\hline \multirow[t]{2}{*}{$\mathrm{X} 15$} & \multirow{2}{*}{$\begin{array}{l}\text { Akibat } \\
\text { percepatan } \\
\text { kerja } \\
\text { membuat } \\
\text { penyedia jasa } \\
\text { harus } \\
\text { mengeluar } \\
\text { kan biaya } \\
\text { yang lebih } \\
\text { besar }\end{array}$} & \multirow[t]{2}{*}{3.56} & \multirow[t]{2}{*}{0.87} & \multirow[t]{2}{*}{5} & & $\begin{array}{l}\text { menyebabkan } \\
\text { kontraktor } \\
\text { harus } \\
\text { mengkaji } \\
\text { kembali } \\
\text { metode tsb }\end{array}$ & & & \\
\hline & & & & & X23 & $\begin{array}{l}\text { Kegagalan } \\
\text { membuat } \\
\text { kesepakatan } \\
\text { harga }\end{array}$ & 2.84 & 1.09 & 16 \\
\hline \multirow[t]{2}{*}{$\mathrm{X} 16$} & \multirow[t]{2}{*}{$\begin{array}{l}\text { Kontraktor } \\
\text { mengeluar } \\
\text { kan sumber } \\
\text { daya dan } \\
\text { waktu yang } \\
\text { lebih banyak }\end{array}$} & \multirow[t]{2}{*}{3.62} & \multirow[t]{2}{*}{0.89} & \multirow[t]{2}{*}{4} & & $\begin{array}{l}\text { perubahan } \\
\text { pekerjaan } \\
\text { antara } \\
\text { kontraktor } \\
\text { dan owner }\end{array}$ & & & \\
\hline & & & & & $\mathrm{X} 24$ & Terdapat isi & 2.76 & 1.09 & 22 \\
\hline \multirow[t]{3}{*}{5} & \multirow{3}{*}{$\begin{array}{l}\text { Penundaan } \\
\text { pekerjaan } \\
\text { dan } \\
\text { penghentian } \\
\text { pekerjaan } \\
\text { oleh } \\
\text { pengguna } \\
\text { jasa } \\
\end{array}$} & & & & & $\begin{array}{lr}\text { kontrak harga } \\
\text { yang tidak } \\
\text { sesuai }\end{array}$ & & & \\
\hline & & & & & 7 & $\begin{array}{l}\text { Perbedaan } \\
\text { gambar } \\
\text { rencana dan } \\
\text { spesifikasi. } \\
\end{array}$ & & & \\
\hline & & & & & \multirow[t]{3}{*}{$\mathrm{X} 25$} & Terjadi & 3.38 & 0.75 & 6 \\
\hline $\mathrm{X} 17$ & $\begin{array}{l}\text { Owner } \\
\text { mengalami } \\
\text { kesulitan } \\
\text { keuangan }\end{array}$ & 2.60 & 0.99 & 27 & & $\begin{array}{l}\text { ketidak } \\
\text { cocokan } \\
\text { antara } \\
\text { gambar yang }\end{array}$ & & & \\
\hline \multirow[t]{2}{*}{$\mathrm{X} 18$} & \multirow{2}{*}{$\begin{array}{l}\text { Persediaan } \\
\text { material } \\
\text { terhambat }\end{array}$} & \multirow[t]{2}{*}{3.00} & \multirow[t]{2}{*}{0.93} & \multirow[t]{2}{*}{13} & & $\begin{array}{l}\text { satu dan yang } \\
\text { lain }\end{array}$ & & & \\
\hline & & & & & $\mathrm{X} 26$ & Mengguna & 3.11 & 1.01 & 10 \\
\hline \multirow[t]{2}{*}{$\mathrm{X} 19$} & $\begin{array}{l}\text { Menghenti } \\
\text { kan semua } \\
\text { pembayaran }\end{array}$ & 2.33 & 0.98 & 28 & & $\begin{array}{l}\text { kan standar } \\
\text { spesifikasi } \\
\text { yang lama }\end{array}$ & & & \\
\hline & pekerjaan & & & & $\mathrm{X} 27$ & Pelaksanaan & 2.80 & 0.97 & 19 \\
\hline $\mathrm{X} 20$ & $\begin{array}{l}\text { Terhambat } \\
\text { pembayaran } \\
\text { dari pihak }\end{array}$ & 2.84 & 1.02 & 17 & & $\begin{array}{l}\text { kerja diluar } \\
\text { urutan } \\
\text { pekerjaan dan }\end{array}$ & & & \\
\hline
\end{tabular}




\begin{tabular}{lllll}
\hline \multicolumn{1}{c}{$\begin{array}{l}\text { tidak sesuai } \\
\text { dengan } \\
\text { gambar yang } \\
\text { ada }\end{array}$} & & & & \\
\hline $\mathrm{X} 28$ & $\begin{array}{l}\text { Gambar yang } \\
\text { diberikan } \\
\text { tidak jelas }\end{array}$ & 3.20 & 0.81 & 9 \\
\hline
\end{tabular}

Hasil analisa memperoleh mean terbesar yaitu 3.82 dan mean terkecil 2.33. Dengan demikian didapat natural cut point sebesar 3.01. berdasarkan nilai natural cut point ini, variabel yang mempunyai mean lebih besar dianggap sebagai faktor penyebab terjadinya klaim konstruksi yang penting untuk diperhatikan. Setelah direduksi berdasarkan nilai natural cut point, didapat 12 variabel yang dikategorikan sebagai faktor penyebab terjadinya klaim konstruksi seperti tabel 2 berikut ini:

Tabel 2 Faktor Penyebab Terjadinya Klaim Konstruksi Berdasarkan Hasil Reduksi

\begin{tabular}{|l|l|l|l|l|}
\hline Kode & $\begin{array}{l}\text { Faktor } \\
\text { Penyebab } \\
\text { Klaim }\end{array}$ & Mean & SD & $\begin{array}{l}\text { Ran } \\
\text { k }\end{array}$ \\
\hline X9 & $\begin{array}{l}\text { Curah hujan } \\
\text { yang lebih } \\
\text { tinggi dari } \\
\text { biasanya } \\
\text { sehingga } \\
\text { menghambat } \\
\text { pekerjaan } \\
\text { proyek }\end{array}$ & 3.82 & 0.81 & 1 \\
\hline X11 & $\begin{array}{l}\text { Hujan deras } \\
\text { yang terus } \\
\text { menerus atau } \\
\text { kondisi cuaca } \\
\text { buruk }\end{array}$ & 3.78 & 0.93 & 2 \\
\hline X13 & $\begin{array}{l}\text { Peningkatan } \\
\text { produktivitas } \\
\text { dengan waktu } \\
\text { lembur lebih } \\
\text { sering terjadi }\end{array}$ & 3.78 & 0.74 & 3 \\
\hline X16 & $\begin{array}{l}\text { Kontraktor } \\
\text { mengeluarkan } \\
\text { sumber daya } \\
\text { dan waktu yang } \\
\text { lebih banyak }\end{array}$ & 3.62 & 0.89 & 4 \\
\hline X15 & $\begin{array}{l}\text { Akibat } \\
\text { percepatan } \\
\text { kerja membuat } \\
\text { penyedia jasa } \\
\text { harus }\end{array}$ & 3.56 & 0.87 & 5 \\
\hline
\end{tabular}

\begin{tabular}{|c|c|c|c|c|}
\hline & $\begin{array}{l}\text { mengeluarkan } \\
\text { biaya yang lebih } \\
\text { besar }\end{array}$ & & & \\
\hline $\mathrm{X} 25$ & $\begin{array}{l}\text { Terjadi ketidak } \\
\text { cocokan antara } \\
\text { gambar yang } \\
\text { satu dan yang } \\
\text { lain }\end{array}$ & 3.38 & 0.75 & 6 \\
\hline $\mathrm{X} 22$ & $\begin{array}{l}\text { Perubahan } \\
\text { metode } \\
\text { pelaksanaan } \\
\text { yang } \\
\text { menyebabkan } \\
\text { kontraktor harus } \\
\text { mengkaji } \\
\text { kembali metode } \\
\text { tsb }\end{array}$ & 3.36 & 0.74 & 7 \\
\hline X14 & $\begin{array}{l}\text { Pekerjaan } \\
\text { dengan waktu } \\
\text { lembur yang } \\
\text { lama membuat } \\
\text { produktivitas } \\
\text { menurun }\end{array}$ & 3.20 & 0.89 & 8 \\
\hline X28 & $\begin{array}{l}\text { Gambar yang } \\
\text { diberikan tidak } \\
\text { jelas }\end{array}$ & 3.20 & 0.81 & 9 \\
\hline X26 & $\begin{array}{l}\text { Menggunakan } \\
\text { standar } \\
\text { spesifikasi yang } \\
\text { lama }\end{array}$ & 3.11 & 1.01 & 10 \\
\hline X5 & $\begin{array}{l}\text { Penyelidikan } \\
\text { tanah yang } \\
\text { dilakukan } \\
\text { owner tidak } \\
\text { sesuai }\end{array}$ & 3.02 & 1.25 & 11 \\
\hline X21 & $\begin{array}{l}\text { Perubahan } \\
\text { gambar oleh } \\
\text { owner }\end{array}$ & 3.02 & 1.06 & 12 \\
\hline
\end{tabular}

Dari tabel 2. diatas diperoleh informasi mengenai rangking/peringkat untuk faktor penyebab terjadinya klaim konstruksi adalah (1) Curah hujan yang lebih tinggi dari biasanya sehingga menghambat pekerjaan proyek, (2) Hujan deras yang terus menerus atau kondisi cuaca buruk, (3) Peningkatan produktivitas dengan waktu lembur lebih sering terjadi, (4) Kontraktor mengeluarkan sumber daya dan waktu yang lebih banyak, (5) Akibat percepatan kerja membuat penyedia jasa harus mengeluarkan biaya yang lebih besar, (6) Terjadi ketidak cocokan antara gambar yang satu dan yang lain, (7) Perubahan metode pelaksanaan yang menyebabkan 
kontraktor harus mengkaji kembali metode tsb, (8) Pekerjaan dengan waktu lembur yang lama membuat produktivitas menurun, (9) Gambar yang diberikan tidak jelas, (10) Menggunakan standar spesifikasi yang lama, (11) Penyelidikan tanah yang dilakukan owner tidak sesuai, (12) Perubahan gambar oleh owner.

\section{Statistik Inferensial}

Menurut Field dalam Sesmiwati (2017), masing-masing item harus memiliki hubungan dengan skor total dari kuesioner. Nilai dalam kolom corrected item-total correlation menunjukkan hubungan ini. Nilai ini harus diatas 0.3 untuk menunjukkan bahwa hubungan yang terjadi antara masing-masing item dengan skor total kuesioner. Jika ditemukan skor kurang dari 0.3 maka item tersebut harus dihilangkan.

Tabel 3 Cronbach's Alpha Item -Total Statistics

\begin{tabular}{|c|c|c|c|c|}
\hline & $\begin{array}{l}\text { Scale } \\
\text { Mean if } \\
\text { Item } \\
\text { Deleted }\end{array}$ & $\begin{array}{l}\text { Scale } \\
\text { Varianc } \\
\text { e if Item } \\
\text { Deleted }\end{array}$ & $\begin{array}{l}\text { Correc } \\
\text { ted } \\
\text { Item- } \\
\text { Total } \\
\text { Correl } \\
\text { ation }\end{array}$ & $\begin{array}{l}\text { Cronb } \\
\text { ach's } \\
\text { Alpha } \\
\text { if Item } \\
\text { Delete } \\
\text { d }\end{array}$ \\
\hline $\begin{array}{l}\text { VAR0 } \\
001\end{array}$ & 125.48 & 973.085 & 0.655 & 0.959 \\
\hline $\begin{array}{l}\text { VAR0 } \\
002\end{array}$ & 126.59 & 984.02 & 0.592 & 0.959 \\
\hline $\begin{array}{l}\text { VAR0 } \\
003\end{array}$ & 125.46 & 986.065 & 0.528 & 0.96 \\
\hline $\begin{array}{l}\text { VAR0 } \\
004\end{array}$ & 126.28 & 990.469 & 0.413 & 0.96 \\
\hline $\begin{array}{l}\text { VAR0 } \\
005\end{array}$ & 125.67 & 984.075 & 0.596 & 0.959 \\
\hline $\begin{array}{l}\text { VAR0 } \\
006\end{array}$ & 125.69 & 983.654 & 0.595 & 0.959 \\
\hline $\begin{array}{l}\text { VAR0 } \\
007\end{array}$ & 126.28 & 987.638 & 0.446 & 0.96 \\
\hline $\begin{array}{l}\text { VAR0 } \\
008\end{array}$ & 126.37 & 973.407 & 0.583 & 0.959 \\
\hline $\begin{array}{l}\text { VAR0 } \\
009\end{array}$ & 125.57 & 972.362 & 0.648 & 0.959 \\
\hline $\begin{array}{l}\text { VAR0 } \\
010\end{array}$ & 125.74 & 973.667 & 0.51 & 0.96 \\
\hline $\begin{array}{l}\text { VAR0 } \\
011\end{array}$ & 125.57 & 972.362 & 0.648 & 0.959 \\
\hline
\end{tabular}

\begin{tabular}{|c|c|c|c|c|}
\hline $\begin{array}{l}\text { VAR0 } \\
012\end{array}$ & 125.89 & 967.384 & 0.677 & 0.959 \\
\hline $\begin{array}{l}\text { VAR0 } \\
013\end{array}$ & 125.96 & 976.678 & 0.746 & 0.959 \\
\hline $\begin{array}{l}\text { VAR0 } \\
014\end{array}$ & 126.43 & 983.117 & 0.55 & 0.96 \\
\hline $\begin{array}{l}\text { VAR0 } \\
015\end{array}$ & 126.26 & 965.177 & 0.635 & 0.959 \\
\hline $\begin{array}{l}\text { VAR0 } \\
016 \\
\end{array}$ & 125.65 & 981.289 & 0.551 & 0.96 \\
\hline $\begin{array}{l}\text { VAR0 } \\
017\end{array}$ & 125.61 & 968.167 & 0.747 & 0.959 \\
\hline $\begin{array}{l}\text { VAR0 } \\
018\end{array}$ & 125.59 & 968.397 & 0.752 & 0.959 \\
\hline $\begin{array}{l}\text { VAR0 } \\
019\end{array}$ & 125.56 & 968.025 & 0.75 & 0.959 \\
\hline $\begin{array}{l}\text { VAR0 } \\
020\end{array}$ & 125.44 & 976.629 & 0.785 & 0.959 \\
\hline $\begin{array}{l}\text { VAR0 } \\
021\end{array}$ & 126.98 & 984.132 & 0.524 & 0.96 \\
\hline $\begin{array}{l}\text { VAR0 } \\
022 \\
\end{array}$ & 126.09 & 981.671 & 0.648 & 0.959 \\
\hline $\begin{array}{l}\text { VAR0 } \\
023\end{array}$ & 126.39 & 973.525 & 0.682 & 0.959 \\
\hline $\begin{array}{l}\text { VAR0 } \\
024\end{array}$ & 126.33 & 982.679 & 0.502 & 0.96 \\
\hline $\begin{array}{l}\text { VAR0 } \\
025\end{array}$ & 126.33 & 982.679 & 0.502 & 0.96 \\
\hline $\begin{array}{l}\text { VAR0 } \\
026\end{array}$ & 125.91 & 973.142 & 0.531 & 0.96 \\
\hline $\begin{array}{l}\text { VAR0 } \\
027\end{array}$ & 125.54 & 967.385 & 0.666 & 0.959 \\
\hline $\begin{array}{l}\text { VAR0 } \\
028\end{array}$ & 125.81 & 978.531 & 0.527 & 0.96 \\
\hline $\begin{array}{l}\text { VAR0 } \\
029\end{array}$ & 125.63 & 979.219 & 0.597 & 0.959 \\
\hline $\begin{array}{l}\text { VAR0 } \\
030\end{array}$ & 125.83 & 969.462 & 0.598 & 0.959 \\
\hline $\begin{array}{l}\text { VAR0 } \\
031\end{array}$ & 125.56 & 974.818 & 0.683 & 0.959 \\
\hline $\begin{array}{l}\text { VAR0 } \\
032\end{array}$ & 126.02 & 973.377 & 0.529 & 0.96 \\
\hline $\begin{array}{l}\text { VAR0 } \\
033\end{array}$ & 126.09 & 974.237 & 0.52 & 0.96 \\
\hline $\begin{array}{l}\text { VAR0 } \\
034\end{array}$ & 125.57 & 974.664 & 0.616 & 0.959 \\
\hline $\begin{array}{l}\text { VAR0 } \\
035\end{array}$ & 125.83 & 973.009 & 0.568 & 0.96 \\
\hline $\begin{array}{l}\text { VAR0 } \\
036\end{array}$ & 125.89 & 968.969 & 0.609 & 0.959 \\
\hline
\end{tabular}

ISSN 2599-2081

Fakultas Teknik UMSB

165 


\begin{tabular}{|c|c|c|c|c|}
\hline $\begin{array}{l}\text { VAR0 } \\
037\end{array}$ & 125.96 & 969.319 & 0.624 & 0.959 \\
\hline $\begin{array}{l}\text { VAR0 } \\
038\end{array}$ & 126.17 & 978.406 & 0.467 & 0.96 \\
\hline $\begin{array}{l}\text { VAR0 } \\
039 \\
\end{array}$ & 126 & 974.377 & 0.519 & 0.96 \\
\hline $\begin{array}{l}\text { VAR0 } \\
040\end{array}$ & 125.61 & 982.657 & 0.632 & 0.959 \\
\hline $\begin{array}{l}\text { VAR0 } \\
041\end{array}$ & 126.22 & 986.289 & 0.459 & 0.96 \\
\hline $\begin{array}{l}\text { VAR0 } \\
042\end{array}$ & 126.24 & 986.526 & 0.455 & 0.96 \\
\hline $\begin{array}{l}\text { VAR0 } \\
043\end{array}$ & 125.52 & 978.896 & 0.575 & 0.959 \\
\hline $\begin{array}{l}\text { VAR0 } \\
044\end{array}$ & 125.67 & 981.509 & 0.435 & 0.96 \\
\hline $\begin{array}{l}\text { VAR0 } \\
045\end{array}$ & 125.93 & 983.693 & 0.634 & 0.959 \\
\hline $\begin{array}{l}\text { VAR0 } \\
046 \\
\end{array}$ & 126.33 & 982.679 & 0.502 & 0.96 \\
\hline $\begin{array}{l}\text { VAR0 } \\
047\end{array}$ & 125.91 & 973.142 & 0.531 & 0.96 \\
\hline $\begin{array}{l}\text { VAR0 } \\
048\end{array}$ & 125.54 & 967.385 & 0.666 & 0.959 \\
\hline $\begin{array}{l}\text { VAR0 } \\
049 \\
\end{array}$ & 125.81 & 978.531 & 0.527 & 0.96 \\
\hline $\begin{array}{l}\text { VAR0 } \\
050\end{array}$ & 125.63 & 979.219 & 0.597 & 0.959 \\
\hline $\begin{array}{l}\text { VAR0 } \\
051\end{array}$ & 125.83 & 969.462 & 0.598 & 0.959 \\
\hline $\begin{array}{l}\text { VAR0 } \\
052\end{array}$ & 125.96 & 969.319 & 0.624 & 0.959 \\
\hline $\begin{array}{l}\text { VAR0 } \\
053\end{array}$ & 126.17 & 978.406 & 0.467 & 0.96 \\
\hline $\begin{array}{l}\text { VAR0 } \\
054\end{array}$ & 126 & 974.377 & 0.519 & 0.96 \\
\hline
\end{tabular}

alpha sebesar 0.960 pada tabel 4 yang artinya variabel pada instrumen penelitian dapat diterima dan baik (berada $>0.8$ ).

\section{SIMPULAN}

Berdasarkan analisa data dapat disimpulkan bahwa :

1. Terdapat 12 variabel (dari 28 variabel) faktor penyebab terjadinya klaim dari kontraktor ke owner pada proyek konstruksi di Kota Padang.

2. Peringkat pertama faktor penyebab terjadinya klaim dari kontraktor ke owner pada proyek konstruksi di Kota Padang adalah Curah hujan yang lebih tinggi dari biasanya sehingga menghambat pekerjaan proyek. Curah hujan yang tinggi tersebut disebabkan oleh terjadinya hujan deras yang terus menerus atau kondisi cuaca yang buruk di Kota Padang (peringkat kedua). Dengan demikian kontraktor melakukan upaya peningkatan produktivitas dengan waktu lembur lebih sering terjadi (peringkat ketiga).

3. Jika faktor penyebab terjadinya klaim dari kontraktor ke owner pada proyek konstruksi di Kota Padang dikelompokkan dalam 3 kategori maka faktor tersebut adalah faktor eksternal, faktor owner, faktor konsultan perencana dan faktor kontraktor.

4. Faktor penyebab eksternal : Curah hujan yang lebih tinggi dari biasanya sehingga menghambat pekerjaan proyek (X9), Hujan deras yang terus menerus atau kondisi cuaca buruk (X11), pemilik proyek : Penyelidikan tanah yang dilakukan owner tidak sesuai (X5), Perubahan gambar oleh owner (X21), Konsultan perencana : Terjadi ketidak cocokan antara gambar yang satu dan yang lain (X25), Menggunakan standar spesifikasi yang lama (X26), Gambar yang diberikan tidak jelas (X28) dan Kontraktor : Perubahan metode pelaksanaan yang menyebabkan kontraktor harus mengkaji kembali metode tsb (X22), Pekerjaan dengan waktu lembur yang lama membuat produktivitas menurun (X14), Peningkatan produktivitas dengan waktu lembur lebih sering terjadi (X13), Akibat percepatan kerja membuat penyedia jasa

$\begin{array}{lr}\text { Fakultas Teknik UMSB } & \text { ISSN 2599-2081 } \\ \text { EISSN 2599-2090 }\end{array}$


harus mengeluarkan biaya yang lebih besar (X15), Kontraktor mengeluarkan sumber daya dan waktu yang lebih banyak (X16).

\section{UCAPAN TERIMAKASIH}

Ucapan terimakasih kepada Direktorat Jenderal Penguatan Riset dan Pengembangan, Kementerian Riset, Teknologi dan Pendidikan Tinggi dan Universitas Bung Hatta yang telah memberikan kesempatan untuk mendapatkan Hibah Penelitian Dosen Pemula tahun 2018.

\section{DAFTAR PUSTAKA}

Andreas Wibowo, (2009), Survei Persepsi Pengajuan Klaim Atas Keterlambatan Akibat Pihak Pemilik Pada Proyek Konstruksi Pemerintah, Konferensi Nasional Teknik Sipil 3, pp. M187-193

Andreas P. Pasaribu, (2009), Faktor Penyebab Terjadinya Klaim yang Mempengaruhi KinerjaWaktu Kinerja Proyek Konstruksi Jalan Tol di Jabodetabek, Thesis, Universitas Indonesia

Chandra H.P, et al, (2005), Studi Tentang Pengajuan Klaim Konstruksi dari Kontraktor ke Pemilik Bangunan, Jurnal Dimensi Teknik Sipil, Vol. 7 No. 2, pp. 9096

I. A. Praniti Tresna Putri, et al, (2013), Analisis Faktor-faktor Yang Menyebabkan Pengajuan Klaim Pelaksanaan Konstruksi Oleh Kontraktor, Jurnal Ilmiah Elektronik Infrastruktur Teknik Sipil, pp. VI.1-VI.7

Lewa, Sondang Dwiputra Paiding dan Harijanto Setiawan. (2017). "Konflik Antara Kontraktor dan Pemilik Proyek yang Berpotensi Menimbulkan Klaim”. Konferensi Nasional Teknik Sipil 11: Universitas Tarumanegera 26-27 Oktober 2017

Nazarkhan Yasin, (2004), Mengenal Klaim Konstruksi dan Penyelesaian Sengketa Konstruksi, Penerbit: Gramedia,Jakarta

Nurisra, dkk, (2009), Faktor Penyebab Pengajuan Klaim Pada Proyek Konstruksi di Banda Aceh, Jurnal Teknik Sipil Universitas Syah Kuala, 7, pp. 93-99

Seng Hansen, (2017), Quantity Surveying: Pengantar Manajemen Biaya dan Kontrak Konstruksi, Penerbit: Gramedia, Jakarta

Sesmiwati, dan Vivi Ariani. (2017). Kajian Mitigasi Keterlambatan Waktu untuk
Meningkatkan Efisiensi Proyek Konstruksi di Sumatera Barat. Universitas Bung Hatta : Penelitian Dosen Pemula Ristek Dikti 2017.

Tela, Nengah dan Nursyam Saleh. (2007). Faktor-Faktor yang Meyebabkan Klaim dan Penyelesaiannya Pada Industri Konstruksi. Universitas Bung Hatta, Padang

Wahida Handayani, dkk, (2010), Studi Persepsi Faktor-faktor Penyebab Klaim Pada Pelaksanaan Proyek Konstruksi Bangunan Gedung, Konferensi Nasional Teknik Sipil 4, pp M89-M96 